No. Issue: 19 | Communication |pp. 132-138

\title{
Strategic Planning of Onion Farming System as Onion Buffer in Indonesia
}

\author{
Ahsin Daroini $^{1, *}$ and Rizky Arief Shobirin ${ }^{2}$ \\ 1 Department of Agribusiness, Faculty of Agriculture, Islamic University of Kadiri; \\ 2 Department of Chemistry, Faculty of Agriculture, Islamic University of Kadiri; \\ * Correspondence: ade@ uniska-kediri.ac.id
}

Received: 19 August 2019; Accepted: 28 August 2019; Published: 30 September 2019

\begin{abstract}
The basic approach that must be taken in the cultivation of onions is to improve soil health, this is because in healthy soils the onion plants will grow well, soil infectious diseases can be suppressed and the effects of weather anomalies can be reduced, so production can be increased with more efficient production costs. Here the proposed Role Model Development of Onion Cultivation System as the National Buffer of Onion Plants, with detailed explanation related to the Agriculture Management System, Operational Management, and Post Harvest Management of Onions.
\end{abstract}

Keywords: Onion; Farm Management System; Operations Management, Post Harvest Management

\section{Introduction}

Long-term price stabilisation efforts require a stable supply of onion bulbs throughout the year at a price level that is affordable for consumers but still profitable for producer farmers. The basic approach that must be taken is to improve soil health, this is because in healthy soils the onion plants will grow well, soil infectious diseases can be suppressed and the effects of weather anomalies can be reduced, so production can be increased with more efficient production costs (Akrofi, et.al., 2016; Haryanti, et.al., 2018).

Land restoration could be done with the application of soil enhancers that aim to improve the biological, physical and chemical fertility of the soil. Biologically fertile soils will reduce soil infectious diseases and increase nutrient uptake, physical fertility will ensure optimum water supply and root growth, and soil chemical fertility will ensure optimum supply of nutrients, which in turn will increase productivity efficiently and economically (Alimi, et.al., 2005; Negasi, et.al., 2013).

Recently many commercial land-enhancing products are circulating, which are claimed to increase soil fertility and crop productivity, but have never been verified in specific environments such as in Nganjuk district. On the other hand soil enhancers can be obtained from the environment around the production land, such as organic materials from livestock farmers that are still not optimized (Alimi, et.al., 2005). In order to stabilize the supply of onion tubers and production efficiency, it is necessary to verify the commercial soil enhancers compared to the local soil amendments and existing farmers' cultivation techniques (Negasi, et.al., 2013; Alimi, et.al., 2005). Verification results are a guide for farmers to get the most efficient and effective production methods in increasing onion production in a sustainable manner (Haq, et.al., 2009; Akrofi, et.al., 2016). So that farmers will get maximum income from farming and remain enthusiastic in maintaining the stability of the price of onions.

\section{Current Onion Farming System}

The awareness of onion farmers is currently low in quality controlling of onions. That is due to the lack of insight related to the cultivation of onions, so that the performance of farmers in 
managing onion farming has not been running optimally. At present, farmers' insights in onion cultivation are only focused on the selection of superior seeds and pest control. Other aspect which may effect on crop yields of onion is still lacking in attention. Soil fertility, good water irrigation, use of appropriate technology was still lacking the attention of farmers (Akrofi, et.al., 2016; Alimi, et.al., 2005; Negasi, et.al., 2013; Haq, et.al., 2009). Therefore, it is necessary to develop a role model of the onion cultivation system so that it can be used as the main reference in managing onion cultivation

\section{Development of Role Model of Onion Farm Management System as a National Buffer for Onions}

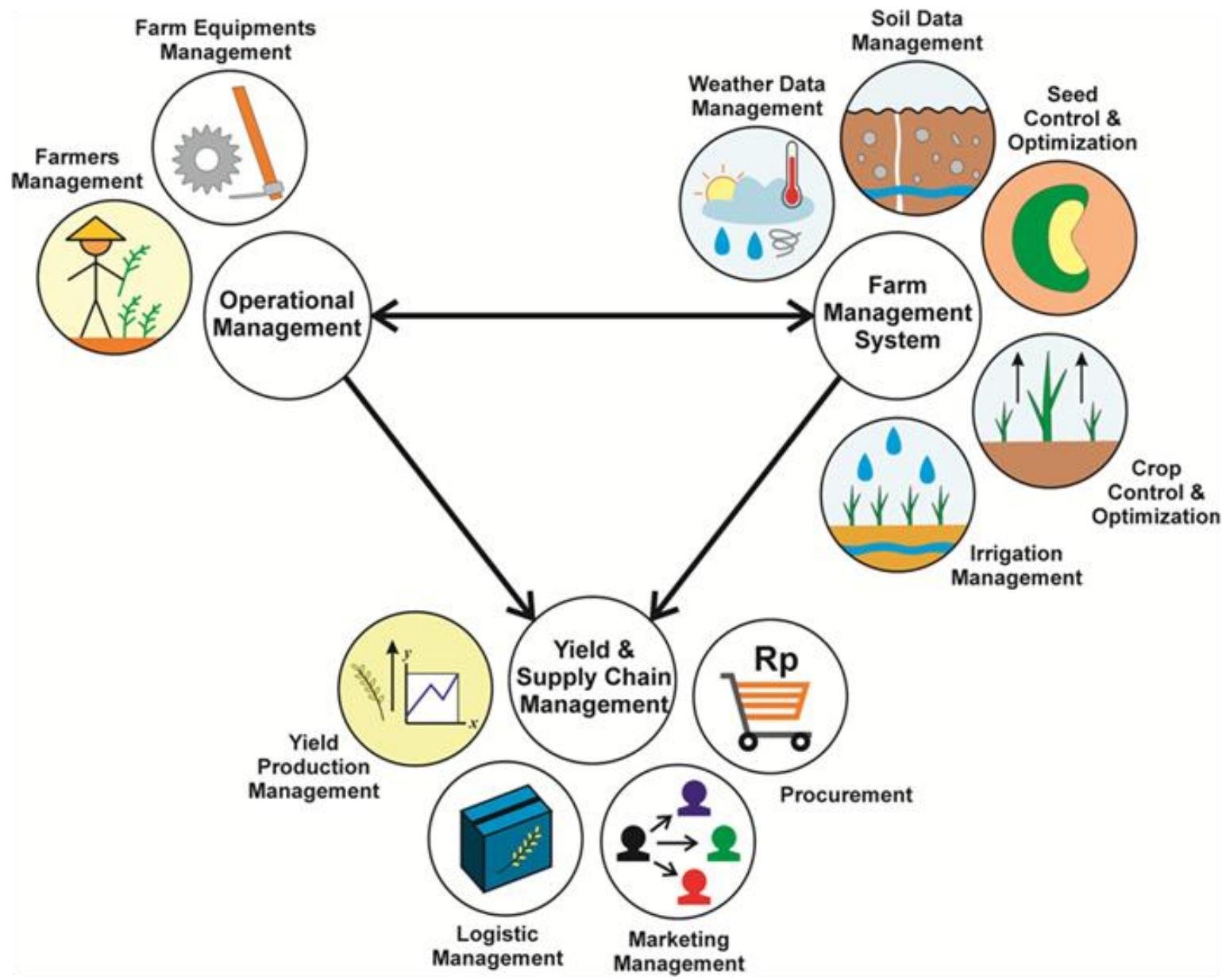

Figure 1. Integrated Farm Management System of Onion Farming, which is going to be started from Farm Management System, synchronized with Operational Management, with the output system of Yield and Supply Chain Management.

On the whole, the agricultural system consists of 3 main rules, including the farm management system, then synchronisation with operational management of farming, and the output of the two management systems is yield and supply chain management, as presented in Figure 1. Farm management system plays a very important role It is important to start planting onions by considering the weather climate of the planting place, suitable soil conditions for planting, selecting and planting seeds, stimulating plant growth and pest control, and regulating water irrigation systems and controlling water quality to support onion farming. The agricultural 
system will run with good operational management, because the results obtained will be good when the agricultural system is run by competent farmers with adequate supporting equipment. Final product of the onion farm also requires arrangements to determine the market price with conditioned stock. Thus, a good result will have a good impact on the welfare of farmers, and still be biased to meet the needs of stock of onions in Indonesia.

\subsection{Onion Farming Management System}

Generally, integrated farming systems are focused on good weather conditions and are suitable for farming, fertile soil conditions that support the growth of shoots from onion seeds, selection of superior seeds to produce good crop yields, good plant growth, progressive, and controlled from pests and diseases, as well as good irrigation arrangements to facilitate plant growth until it is ready for harvest. Overall, the onion farming management system is presented in Figure 2.

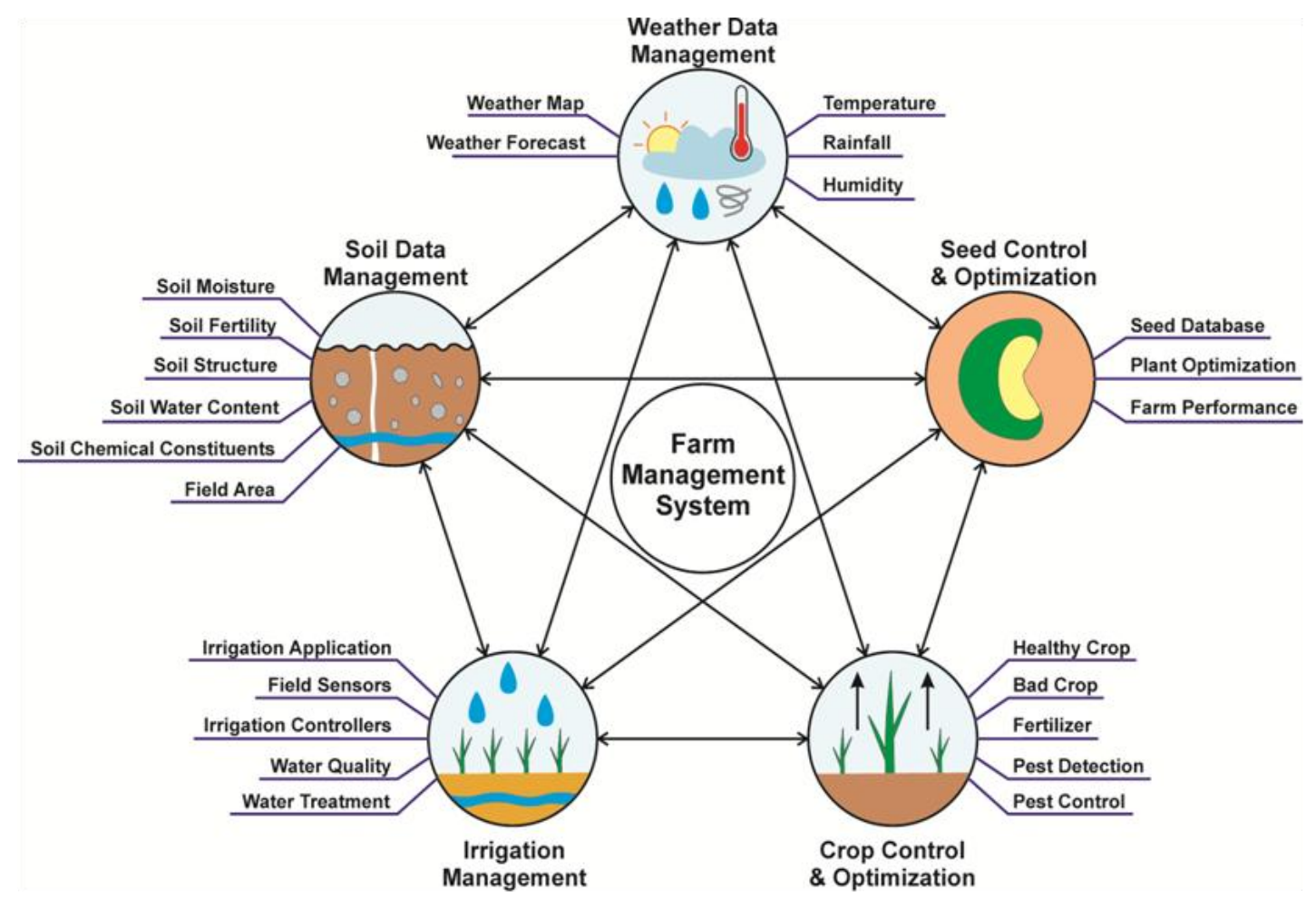

Figure 2. Schematic diagram of Farm Management System of Onion Farming, which each factors has specific parameters in order to control bawang merah cultivation and growth in best condition.

Knowledge related to weather conditions at the planting location is very important to study for farmers, because it will greatly affect the growth of onion plants and plant resistance to climate and weather change. Observing for weather conditions on a regular basis is felt to be quite helpful in preparing preventive measures so that the onion plants can continue to grow well. In addition, other conditions such as temperature, rainfall and humidity, need to be monitored continuously as well because it affects the growth of these plants (Akrofi, et.al., 2016; Haq, et.al., 2009).

Soil condition is one of the main concerns in onion cultivation, because soil is a medium of plant for growth. Moisture and soil fertility become one of the main parameters in selecting the right soil for planting onions, for the reason that it is related to the availability of key nutrients for 
plant growth. Soil structure is also being an important consideration, because it is the main media for plant root growth and bud growth from seed that has been planted (Negasi, et.al., 2013). Availability of water in the soil is also important because the onion plants also need high enough water. Another thing to note is the content of elements and chemical compounds in the soil for the fulfilment of certain nutrients for onion plants, such as magnesium for photosynthesis (Akrofi, et.al., 2016). The last parameter of soil data management is the area for planting, because it is related to the fulfilment of the capacity of onions that can be planted until harvest (Akrofi, et.al., 2016; Negasi, et.al., 2013).

Besides land, the other aspect that needs attention is water irrigation. Water irrigation management is very crucial to be considered, since almost all plants need water for living foam and growing. Irrigation systems need to be regulated and controlled for equitable water distribution in all fields so that all onion plants can grow optimally. In addition to the water irrigation system, water quality also needs to be considered so that the water absorbed by the plant is good and helps the process of seed growth and the onion plant reach the conditions ready for harvest. Water quality condition control is also taken into account, such as irrigated water pollution in plants (Akrofi, et.al., 2016). In this case, handling water quality that is not good requires water irrigation management techniques, for example filtering, sedimentation, and $\mathrm{pH}$ regulation, in order to get back good water quality for plant growth.

The selection and optimization of seed growth are the focus of attention in onion farming. Seed selection is explored by knowing the profile of each seed variant in detail, in order to know the characteristics of the seed to grow to harvest, as well as knowing other things that need to be considered so that the seeds can germinate properly and grow optimally (Akrofi, et.al., 2016).

Control and optimization of plant growth is a further stage after the seeds have sprouted. In this case, fulfilment of plant nutrition plays a very important role. Giving correct type of fertilizer with the right dose will greatly help plant growth. Furthermore, it is also necessary to control the condition of plants that are growing, such as investigating diseased plants. Diseased plants are usually caused by ailments, bugs, and viruses. Therefore, it needs to be treated medically to cure the disease and so as not to infect other plants. In addition, plant supervision is necessity to be done related to pest attacks. Pests become intruders from the outside because it can cause damage and death to plants if it is not supervised (Alimi, et.al., 2005; Akrofi, et.al., 2016).

The management of the onion farming system is indeed reasonably complex, because it takes into account various factors that can affect whole farming process which is from germination, growth, to harvesting of the onion plants. In addition, it is necessary to observe and supervise various other factors that can hinder the process of seeding, growth, to harvesting onions.

\subsection{Operational Management of Onion Agriculture}

Onion operational management also plays an important role, because it is related to the implementation of the onion farm management system. Basically, operational management is divided into two aspects, including farmer management and equipment management, as shown in Figure 3.

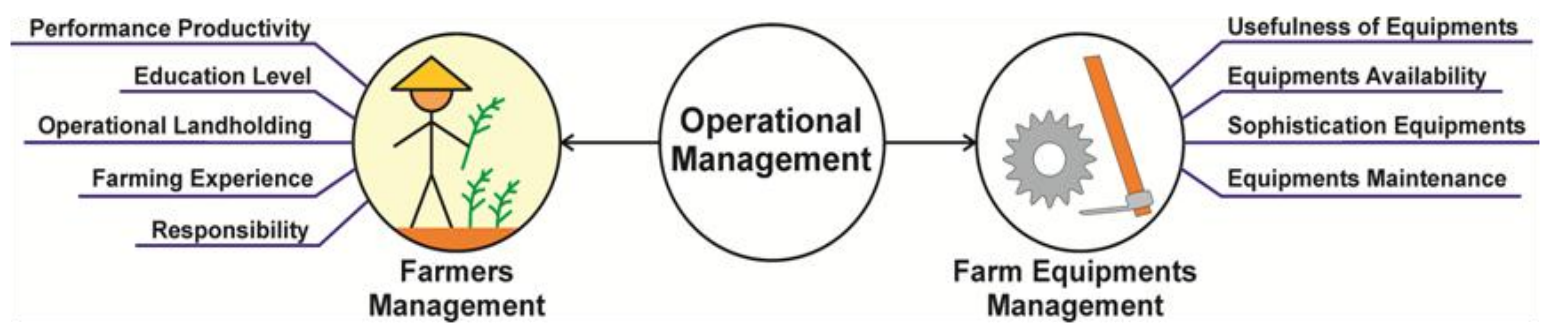

Figure 3. An in line diagram of Operational Management of Onion Farming. 
Farmers are the main implementers of operational management of onion farming. Farmers who meet the criteria both as managers of onion farming will have a good impact on agricultural output. In short, good farmers have productive work in routine, extensive and in-depth agricultural knowledge related to onion plants (Haq, et.al., 2009; Akrofi, et.al., 2016). Farmers who meet the criteria also have competent skills in solving problems that occur in the field. Their experience in growing onions is the basic in determining the criteria of good farmers. Moreover, a high sense of responsibility should also be held by the farmer so that the continuity of the suitable planting of onions can be controlled properly, so that an optimal harvest can be obtained.

Equipment management also plays a position in the operation of onion cultivation. The initial process of farming from planting to harvesting onions requires adequate and advanced equipment. Of course, regular maintenance is needed to keep the equipment used in good condition for growing onions.

\subsection{Onion Post Harvest Management}

This section focuses on post-harvest management of onions, as presented in Figure 4. Yields of onions, from commodities to quality, will contribute to the selling price of the onions (Haryanti, et.al., 2018). In addition, logistics management and marketing will also affect the market price of the onions. In addition, quality control of onion yields determines the stability of the onion market price in Indonesia.

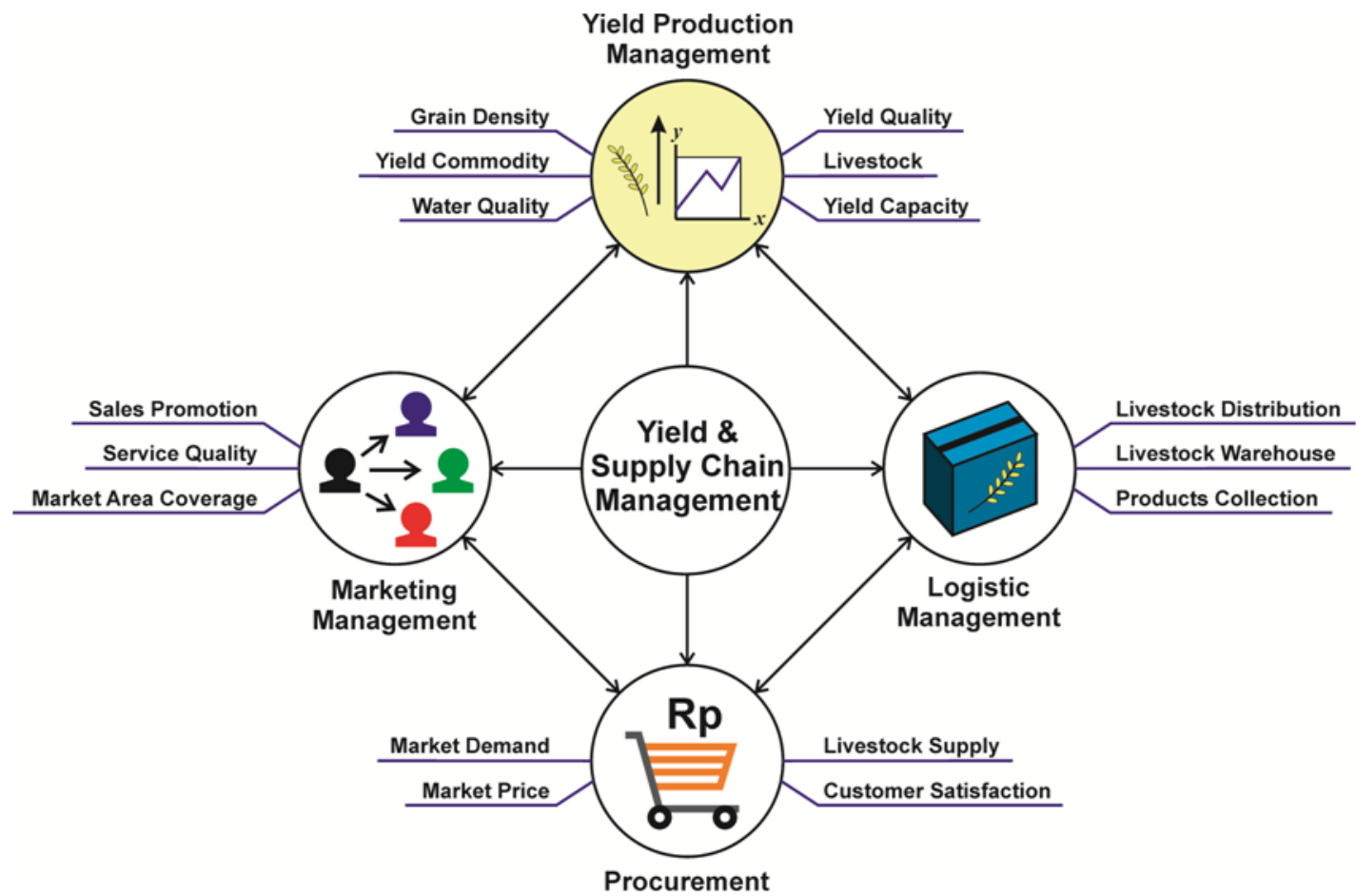

Figure 4. Schematic diagram of Yield Production Management, Logistic Management, Marketing Management, and Procurement, which integrated as Yield and Supply Chain Management.

\section{Future Insight and Developments}

Socialisation is necessity to support the insights of farmers in managing onion agriculture. The focus of the socialisation and training substance could be centred on the management of soil nutrition control and water irrigation. Socialisation related to preventive measures against the 
weather is also essential to keep the onion plants under control and run well. Additional insight is also requisite regarding the types and procedures of pest and disease control, so that the onion plants can still grow until a good harvest is obtained.

Further efforts are the attention of the local government towards the development of onion farming systems in order to meet food needs related to onions in Indonesia. The government be capable of help onion cultivation managers in land management, water irrigation system engineering assistance, procurement of more sophisticated equipment for the process of pirating and harvesting onions, as well as support for the application of the proposed role model so that it can be applied as the main reference for onion cultivation systems as buffer for onions on a national scale.

\section{Acknowledgement}

The authors would like to contribute through this paper for sight open the horizons of farmers in Indonesia for realise better agricultural cultivation management system, specifically for onions. The authors have no conflict of interest.

\section{References}

Akrofi, S.; Kotey, D.A.; Ahiatsi, E.N.; Larbi-Koranteng, S. Onion Farming Practices in Eastern Region of Ghana: Omplications for Research. Asian Journal of Agriculture and Food Sciences, 2016, 4(4), pp. 179-190.

Alimi, T.; Ayanwale, A.B. Risk and Risk Management in Onion Production in Kebbi State of Nigeria. Journal of Social Sciences, 2005, 10(1), pp. 1-8.

Haq, Z.U.; Ishaq, M.; Farooq, A.; Saddozai, K.N.; Yaqoob, S.; Shah, M. Effect of Farmers' Characteristics on Onion Yield. Sarhad Journal of Agriculture, 2009, 25(4), pp. 523-528.

Negasi, T.A.; Nugissie, D.R.; Kebede, W.; Lemma, D.; Abuhay, T. Characterization of Soil Nutrient Management and Post-harvest Handling Practices for Onion Production in Central Rift Valley Region of Ethiopia. Agriculture, Foresty, and Fisheries, 2013, 2(5), pp. 184-195.

Haryanti, D.M.; Kusumawardhani, M.; Anshar, K. Indonesia: Inclusive Business in Indonesia - Improving Supply Chain Efficiency through Inclusive Business. Asian Development Bank, Technical Assistance Consultant's Report, 2018, Project Number: TA-8550. 